\title{
Pengaruh Pemberian Pupuk Organik Kascing dan Pupuk Organik Cair Top G2 Terhadap Pertumbuhan Bibit Pinang
}

\author{
Rudi Fadhli, Nuryulsen Safridar $*^{1}$ \\ ${ }^{1}$ Program Studi Agroteknologi, Fakultas Pertanian, Universitas Jabal Ghafur, Sigli-Indonesia. \\ *Email korespondensi: rudifadhli@unigha.ac.id ${ }^{1}$
}

\begin{abstract}
Abstrak:
Upaya pengembangan tanaman pinang, penyediaan bibit merupakan salah satu faktor yang menentukan dalam peremajaan dan perluasan areal penanaman pinang. Selama ini perbanyakan pinang dilakukan secara konvensional yang sampai sekarang masih menghadapai banyak kendala. Kendala tersebut antara lain lamanya waktu yang diperlukan untuk perkecambahan dari benih dan rentannya bibit terhadap kondisi lingkungan, serta serangan dari hama dan penyakit khususnya persemaian bibit pinang. Salah satu kegiatan pemeliharaan adalah melakukan pemupukan yang bertujuan untuk menambah unsur hara yang dibutuhkan tanaman. Tanpa adanya penambahan unsur hara melalui pemupukan, pertumbuhan dan perkembangan bibit maka pertumbuhan akan menjadi lambat. Tujuan dari penelitian ini adalah untuk mengetahui pengaruh pupuk organik kascing dan pupuk organik cair TOP G2 terhadap pertumbuhan bibit pinang. Penelitian dilakukan dalam kebun percobaan Fakultas Pertanian Universitas Jabal Ghafur Sigli dari bulan September sampai Desember 2015 dengan menggunakan rancangan acak kelompok pola faktorial melalui tiga ulangan, yaitu faktor pupuk organik kascing dengan taraf: 0 gram polibag-1 (K0), 37,5 gr/polibag-1 (K1), 75,0 gr/polibag-1 (K2) dan 112,5 gr/polibag-1 (K3)yang terdiri dan faktor pupuk organik cair G2 dengan taraf: 0 cc/liter air/polibag (T0), 1 cc/liter air/polibag (T1), 2 cc/liter air/polibag (T2) dan 3 cc/liter air/polibag (T3). Hasil penelitihan menunjukkan pemberian pupuk organik baik kascing maupun cair Top G2 memberikan daya pertumbuhan bibit tanaman pinang pada tinggi tanaman dan perkembangan akar tanaman dengan masing masing takaran jenis pupuk organik kascing terbaik pada 112,5 gr/polibag dan pupuk organik cair Top G2 terbaik pada takaran 4 cc/liter/polibag.
\end{abstract}

Kata kunci : Pupuk Organik Kascing, Pupuk Organik Cair Top G2, dan Bibit Pinang 
Upaya untuk pengembangan tanaman pinang, penyediaan bibit merupakan salah satu faktor yang menentukan dalam peremajaan dan perluasan areal penanaman pinang. Selama ini perbanyakan pinang dilakukan secara konvensional yang sampai sekarang masih menghadapai banyak kendala. Kendala tersebut antara lain lamanya waktu yang diperlukan untuk perkecambahan dari benih dan rentannya bibit terhadap kondisi lingkungan, serta serangan dari hama dan penyakit (Bustamam, dkk., 2004).

Untuk menunjang keberhasilan pengembangan pinang khususnya persemaian bibit pinang, perlu adanya kegiatan pemeliharaan yang memadai di pembibitan. Salah satu kegiatan pemeliharaan adalah melakukan pemupukan yang bertujuan untuk menambah unsur hara yang dibutuhkan tanaman. Tanpa adanya penambahan unsur hara melalui pemupukan, pertumbuhan dan perkembangan bibit, yang hanya bergantung pada persediaan hara yang ada di dalam media tanah, maka pertumbuhan akan menjadi lambat (Wahyudi dan Hatta, 2009).

Pemupukan merupakan salah satu cara untuk memperbaiki tingkat kesuburan tanah dan meningkatkan pertumbuhan dan produksi tanaman. (Nyakpa dan Har, 1985). Pemupukan dapat dilakukan dengan memakai bahan kimiawi ataupun bahan organik. Penggunaan pupuk organik seperti organik kascing merupakan salah satu pemupukan alternatif dalam usaha meningkatkan kualitas bibit.

Kascing merupakan pupuk organik plus yang berasal dari kotoran cacing tanah yang kaya akan unsur hara nitrogen $(\mathrm{N})$, fospor $(\mathrm{P})$, kalium $(\mathrm{K})$, kalsium $(\mathrm{Ca})$, magnesium $(\mathrm{Mg})$ serta hormon tumbuh seperti auksin, sitokinin dan giberillin yang sangat di butuhkan tanaman (Radian, 1996).

Disamping pemberian pupuk organik kascing, perlu juga dilakukan pemberian nutrien yang ramah lingkungan untuk meningkatkan pertumbuhan bibit seperti pupuk organik Cair Top G2 yang dibuat dari bahan organik pilihan (hewan dan tanaman), bukan berasal dari bahan sampah/limbah, sehingga tidak mengandung racun atau mikroba yang berbahaya bagi kesehatan, serta ramah lingkungan. Diproduksi berdasarkan formula Bioteknologi dengan presisi tingkat tinggi melaluli Fermentasi dan Enzimik. TOP G2 mengandung hormon pengatur tumbuh Zeatin, Gibrelin (Ga3) serta 14 bentuk Mineral Essential (Hara Makro/Mikro lengkap) dan juga 17 bentuk Asam Amino, Vitamin, dan berbagai Mikro Flora. Top G2 cepat diserap tanaman untuk meningkatkan penyerapan unsur-unsur hara (Health Wealth International, 2010).

Tanaman yang kekurangan unsur nitrogen memperlihatkan pertumbuhan yang terganggu seperti tumbuh kerdil, sistem perakarannya terbatas, daun akan berwarna kekuning-kuningan (klorosis), jaringan tanaman mengering dan mati. Sebaliknya, kelebihan nitrogen juga memberikan pengaruh buruk terhadap pertumbuhan tanaman.

Berdasarkan latar belakang yang telah diuraikan, timbulah suatu pemikiran untuk mengadakan penelitian terhadap pertumbuhan bibit pinang dengan perlakuan pupuk organik kascing dan pupuk organik cair.

Tujuan penelitian untuk mengetahui pengaruh 
pupuk organik kascing dan pupuk organik cair TOP G2 terhadap pertumbuhan bibit pinang.

\section{TINJAUAN PUSTAKA}

\section{Peranan Pupuk Organik Kascing}

Penggunaan kascing merupakan salah satu upaya untuk memperbaiki sifat fisik tanah meningkatkan pertumbuhan dan produksi tanaman (Sulastri, dkk., 2013). Pemberian kascing pada tanah dapat memperbaiki sifat fisik tanah memperbaiki struktur tanah, porositas, permeabilitas, meningkatkan kemampuan untuk menahan air.

\section{Peranan Pupuk Organik Cair}

TOP G2 sekaligus juga berfungsi merehabilitasi, meningkatkan dan mempertahankan kesuburan lapisan-lapisan tanah yang diolah, sehingga dapat meningkatkan pertumbuhan dan kualitas tanaman secara signifikan. Keunggulan menggunakan pupuk organik cair TOP G2, yaitu: Pupuk lengkap dan pembenah tanah, spesifikasi kandungan isi komplit (Full Spec), ramah lingkungan dan tidak mengandung racun serta kadar bakteri bibit penyakit, merangsang pertumbuhan dan kualitas kinerja akar tanaman secara sempurna, (Health Wealth International, 2010).

\section{METODE PENELITIAN}

Penelitian dilakukan pada kebun percobaan Fakultas Pertanian Universitas Jabal Ghafur Sigli dari bulan September sampai dengan Desember 2015. Bahan dan alat yang digunakan dalam penelitian ini adalah benih pinang, pupuk organik kascing, pupuk organik cair G2, polybag dan tanah topsoil serta alat kelengkapan lain dalam menunjang penelitian. Rancangan Acak Kelompok (RAK) pola faktorial diguanakan dalam penelitian ini, yang terdiri dari dua faktor. Faktor pupuk organik kascing,

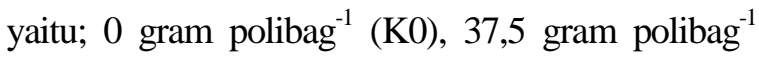
(K1), 75,0 gram polibag ${ }^{-1}$ (K2) dan 112,5 gram polibag $^{-1}(\mathrm{~K} 3)$. Faktor pupuk organik cair G2, yaitu; 0 cc/liter air/polibag (T0), 1 cc/liter air/polibag (T1), 2 cc/liter air/polibag (T2) dan 3 cc/liter air/polibag (T3) dengan dengan tiga ulangan atau terdapat 48 unit satuan.

\section{HASIL DAN PEMBAHASAN}

\section{Pengaruh Pemberian Pupuk Organik Kascing}

\section{A. Tinggi Bibit Tanaman Pinang}

Hasil penelitian menunjukkan bahwa faktor pemberian pupuk organik kascing berpengaruh sangat nyata terhadap tinggi bibit pinang pada umur 30, 60, dan 90 hst, dengan tinggi rata-rata bibit pinang dapat dilihat pada Tabel 1, yang memperlihatkan bibit pinang tertinggi umur 30 , 60 dan 90 hst dijumpai pada takaran 112,5 gram polibag $^{-1}\left(\mathrm{~K}_{3}\right)$ yaitu masing-masing $30,13 \mathrm{~cm}$, $33,83 \mathrm{~cm}$ dan $36,18 \mathrm{~cm}$.

Tabel 1. Rata-rata Tinggi Bibit Pinang Umur 30, 60 dan 90 HST Akibat Pemberian Pupuk Organik Kascing.

\begin{tabular}{rccc}
\hline \multirow{2}{*}{$\begin{array}{c}\text { Pupuk Organik } \\
\text { Kascing } \\
\left(\text { gr polibag }^{-1}\right)\end{array}$} & \multicolumn{3}{c}{ Tinggi Bibit (cm) } \\
\cline { 2 - 4 } & $30 \mathrm{hst}$ & $60 \mathrm{hst}$ & $90 \mathrm{hst}$ \\
\hline 0 & $24,05 \mathrm{a}$ & $26,93 \mathrm{a}$ & $30,74 \mathrm{ab}$ \\
37,5 & $25,03 \mathrm{ab}$ & $27,30 \mathrm{a}$ & $30,42 \mathrm{a}$ \\
75,0 & $29,18 \mathrm{bc}$ & $33,18 \mathrm{~b}$ & $34,90 \mathrm{bc}$ \\
112,5 & $30,13 \mathrm{c}$ & $33,83 \mathrm{~b}$ & $36,18 \mathrm{c}$ \\
\hline BNJ 0,05 & 4,69 & 4,51 & 4,46 \\
\hline
\end{tabular}

Ket : Angka yang diikuti oleh huruf yang sama pada kolom yang sama berbeda tidak nyata pada $\operatorname{taraf} \alpha=5 \%$ (Uji BNJ)

Adanya keseimbangan unsur hara yang sesuai dengan kebutuhan yang dibutuhkan tanaman 
menyebabkan unsur hara tersebut tersedia dengan cukup. Simamora (2006) menyatakan bahwa suatu tanaman akan tumbuh subur apabila segala unsur hara yang dibutuhkan cukup tersedia dalam bentuk yang sesuai untuk diserap tanaman.

\section{B. Diameter Pangkal Batang dan Jumlah Helai Daun Bibit Tanaman Pinang}

Diameter pangkal batang bibit pinang pada umur 30, 60, dan 90 hst tidak menunjukkan pengaruh yang nyata oleh faktor pemberian pupuk organik kascing. Diameter pangkal batang rata-rata bibit pinang dapat dilihat pada Tabel 2

Tabel 2. Rata-rata Diameter Pangkal Batang Bibit Pinang Umur 30, 60 dan 90 HST Akibat Pemberian Pupuk Organik Kascing.

\begin{tabular}{rrrr}
\hline $\begin{array}{c}\text { Pupuk Organik } \\
\text { Kascing } \\
\left(\text { gr polibag }^{-1}\right)\end{array}$ & \multicolumn{3}{c}{ Diameter Batang (cm) } \\
\cline { 2 - 4 } & $30 \mathrm{hst}$ & $60 \mathrm{hst}$ & $90 \mathrm{hst}$ \\
\hline 0 & 1,65 & 2,03 & 2,22 \\
37,5 & 1,64 & 1,92 & 2,06 \\
75,0 & 1,72 & 1,98 & 2,10 \\
112,5 & 1,67 & 1,96 & 2,08 \\
\hline BNJ 0,05 & - & - & - \\
\hline Ket : Angka yang diikuti oleh huruf yang & sama \\
pada kolom yang sama berbeda tidak nyata \\
pada taraf $\alpha=5 \%$ (Uji BNJ)
\end{tabular}

Sedangkan jumlah helai daun menunjukkan faktor pupuk organik kascing berpengaruh sangat nyata pada umur 60 HST yang dapat dilihat pada Tabel 3 dengan jumlah helai daun terbanyak pada takaran 112,5 gr.polibag ${ }^{-1}$ yang tentunya tidak berbeda nyata dengan takaran 75,0 dan 37,5 gr.polibag-1 .

Tabel 3. Rata-rata Jumlah Helai Daun Bibit Pinang Umur 30, 60 dan 90 HST Akibat Pemberian Pupuk Organik Kascing.

\begin{tabular}{rccc}
\hline $\begin{array}{c}\text { Pupuk Organik } \\
\text { Kascing } \\
\left(\text { gr polibag }^{-1}\right)\end{array}$ & \multicolumn{3}{c}{ Jumlah Helai Daun } \\
\cline { 2 - 4 } & $30 \mathrm{hst}$ & $60 \mathrm{hst}$ & $90 \mathrm{hst}$ \\
\hline 0 & 1,14 & $1,79 \mathrm{a}$ & 2,17 \\
37,5 & 1,22 & $1,92 \mathrm{ab}$ & 2,11 \\
75,0 & 1,17 & $2,00 \mathrm{ab}$ & 2,25 \\
112,5 & 1,14 & $2,04 \mathrm{~b}$ & 2,18 \\
\hline
\end{tabular}

\begin{tabular}{l}
\hline BNJ 0,05 - 0,26 \\
Ket : Angka yang diikuti oleh huruf yang sama \\
pada kolom yang sama berbeda tidak nyata \\
pada taraf $\alpha=5 \%$ (Uji BNJ).
\end{tabular}

Pemberian kascing juga mampu mempengaruhi kandungan K tanah. Soepardi (1983) menyatakan peningkatan unsur hara $\mathrm{K}$ akan merangsang pembukaan stomata sehingga meningkatkan proses penangkapan energi matahari, yang diikuti pengambilan $\mathrm{CO}_{2}$ dan pengeluaran $\mathrm{O}_{2}$ melalui proses respirasi kemudian mengubahnya menjadi energi biokimia. Terdapatnya unsur $\mathrm{K}$ yang mampu berperan sebagai pengatur proses fisiologi tanaman seperti fotosintesis, akumulasi, transportasi karbohidrat, membuka menutupnya stomata atau mengatur distribusi air dalam jaringan dan sel, berperan sebagai katalisator enzim pada proses metabolisme tanaman serta meningkatkan translokasi karbondioksida $\left(\mathrm{CO}_{2}\right)$.

\section{Pengaruh Pemberian Pupuk Organik Cair Top G2}

\section{A. Tinggi Bibit Tanaman Pinang}

Hasil penelitian menunjukkan bahwa faktor pemberian pupuk organik cair Top G2 berpengaruh sangat nyata terhadap tinggi bibit pinang pada umur 30, 60, dan 90 hst, dengan tinggi rata-rata bibit pinang dapat dilihat pada Tabel 4, yang memperlihatkan bibit pinang tertinggi umur 30, 60 dan 90 hst dijumpai pada takaran 4,0 cc/liter air/polibag $\left(\mathrm{T}_{3}\right)$ yaitu masingmasing $30,04 \mathrm{~cm}, 33,61 \mathrm{~cm}$ dan $36,42 \mathrm{~cm}$. 
Tabel 4. Rata-rata Tinggi Bibit Pinang Umur 30, 60 dan 90 HST Akibat Pemberian Pupuk Organik Kascing.

\begin{tabular}{rccc}
\hline \multirow{2}{*}{$\begin{array}{c}\text { Organik Cair } \\
\text { Top G2 } \\
\text { (cc/liter } \\
\text { air/polibag) }\end{array}$} & $30 \mathrm{hst}$ & $60 \mathrm{hst}$ & $90 \mathrm{hst}$ \\
\cline { 2 - 4 } Tinggi Bibit (cm) \\
\hline 1,0 & $24,43 \mathrm{a}$ & $27,77 \mathrm{a}$ & $30,81 \mathrm{a}$ \\
2,0 & $26,08 \mathrm{ab}$ & $28,36 \mathrm{a}$ & $31,43 \mathrm{a}$ \\
3,0 & $27,83 \mathrm{ab}$ & $31,50 \mathrm{ab}$ & $33,60 \mathrm{ab}$ \\
4,0 & $30,04 \mathrm{~b}$ & $33,61 \mathrm{~b}$ & $36,42 \mathrm{~b}$ \\
\hline BNJ 0,05 & 4,69 & 4,51 & 4,46 \\
\hline
\end{tabular}

Ket : Angka yang diikuti oleh huruf yang sama pada kolom yang sama berbeda tidak nyata pada $\operatorname{taraf} \alpha=5 \%$ (Uji BNJ)

Adanya faktor internal yang mempengaruhi pertumbuhan tanaman diantaranya adalah laju fotosintetik, respirasi, klorofil, karoten dan kandungan pigmen lainnya. Sedangkan faktor eksternal yang mempengaruhi pertumbuhan tanaman diantaranya adalah iklim yang meliputi cahaya, temperatur, air, panjang hari, angin dan gas. Faktor eksternal yang lain adalah edafik (tanah) yang meliputi tekstur, struktur, bahan organik, kapasitas pertukaran kation, $\mathrm{pH}$ dan kejenuhan basa (Gardner, 1991).

\section{B. Diameter Pangkal Batang dan Jumlah Helai Daun Bibit Tanaman Pinang}

Sama dengan faktor pemberian pupuk organik kascing, diameter pangkal batang bibit pinang pada umur 30, 60, dan 90 hst tidak menunjukkan pengaruh yang nyata oleh faktor pemberian pupuk organik cair Top G2. Diameter pangkal batang ratarata bibit pinang dapat dilihat pada Tabel 5.

Tabel 5. Rata-rata Diameter Pangkal Batang Bibit Pinang Umur 30, 60 dan 90 HST Akibat Pemberian Pupuk Organik Cair Top G2.

\begin{tabular}{cccc}
\hline Organik Cair & \multicolumn{3}{c}{ Diameter Batang $(\mathrm{cm})$} \\
\cline { 2 - 4 } $\begin{array}{c}\text { Top G2 } \\
\text { (cc/liter }\end{array}$ & $30 \mathrm{hst}$ & $60 \mathrm{hst}$ & $90 \mathrm{hst}$ \\
air/polibag) & & & \\
\hline
\end{tabular}

\begin{tabular}{rlll}
\hline 1,0 & 1,63 & 1,94 & 2,08 \\
2,0 & 1,68 & 1,94 & 2,11 \\
3,0 & 1,70 & 2,00 & 2,17 \\
4,0 & 1,67 & 2,00 & 2,10 \\
\hline BNJ 0,05 & - & - & - \\
\hline
\end{tabular}

Ket : Angka yang diikuti oleh huruf yang sama pada kolom yang sama berbeda tidak nyata pada taraf $\alpha=5 \%$ (Uji BNJ)

Demikian pula yang terlihat pada jumlah helai daun menunjukkan faktor pupuk organik cair Top G2 yang tidak berpengaruh sangat nyata seperti yang terlihat pada Tabel 6.

Tabel 6 . Rata-rata Jumlah Helai Daun Bibit Pinang Umur 30, 60 dan 90 HST Akibat Pemberian Pupuk Organik Kascing (cm).

\begin{tabular}{rccc}
\hline \multirow{2}{*}{$\begin{array}{c}\text { Organik Cair } \\
\text { Top G2 } \\
\text { (cc/liter } \\
\text { air/polibag) }\end{array}$} & \multicolumn{3}{c}{ Jumlah Helai Daun } \\
\cline { 2 - 4 } 1,0 & 1,31 & 1,93 & 2,25 \\
2,0 & 1,11 & 1,94 & 2,17 \\
3,0 & 1,14 & 1,93 & 2,14 \\
4,0 & 1,11 & 1,94 & 2,15 \\
\hline BNJ 0,05 & - & - & -
\end{tabular}

Ket: Angka yang diikuti oleh huruf yang sama pada kolom yang sama berbeda tidak nyata pada taraf $\alpha=5 \%$ (Uji BNJ).

Ada peran dari hara hara mikro yang kurang terpenuhi oleh bibit pinang sehingga berdampak pada daya tumbuh kembang tanaman.

\section{Panjang Akar}

Panjang akar bibit pinang menunjukkan bahwa faktor pemberian pupuk organik kascing berpengaruh tidak nyata terhada Panjang Akar Bibit Pinang. Rata-rata Panjang Akar Bibit Pinang 90 HST akibat pemberian pupuk organik kascing dapat dilihat pada Tabel 7.

Tabel 7. Rata-rata Panjang Akar Bibit Pinang Umur 30, 60 dan 90 HST Akibat Pemberian Pupuk Organik Kascing (cm).

\begin{tabular}{|c|c|c|c|}
\hline \multirow{2}{*}{$\begin{array}{l}\text { Pupuk Organik } \\
\text { Kascing } \\
\left(\text { gr polibag }^{-1}\right)\end{array}$} & \multicolumn{3}{|c|}{ Diameter Batang $(\mathrm{cm})$} \\
\hline & $30 \mathrm{hst}$ & $60 \mathrm{hst}$ & 90 hst \\
\hline
\end{tabular}




\begin{tabular}{rccc}
\hline 0 & 1,14 & $1,79 \mathrm{a}$ & 2,17 \\
37,5 & 1,22 & $1,92 \mathrm{ab}$ & 2,11 \\
75,0 & 1,17 & $2,00 \mathrm{ab}$ & 2,25 \\
112,5 & 1,14 & $2,04 \mathrm{~b}$ & 2,18 \\
\hline BNJ 0,05 & - & 0,26 & - \\
\hline
\end{tabular}

Ket : Angka yang diikuti oleh huruf yang sama pada kolom yang sama berbeda tidak nyata pada taraf $\alpha=5 \%$ (Uji BNJ).

\section{KESIMPULAN DAN SARAN}

\section{Kesimpulan}

Adapun beberapa kesimpulan yang dapat ditarik berdasarkan hasil penelitian ini adalah sebagai berikut :

1. Pemberian pupuk organik kascing dan cair hanya berpengaruh sangat nyata terjadi pada tinggi bibit pada umur 30, 60 dan 90 HST serta panjang akar.

2. Pemberian pupuk organik kascing pada diameter batang berpengaruh sangat nyata pada umur $60 \mathrm{HST}$.

\section{Saran}

Penggunaan pupuk organik memiliki fungsi yang sama dengan kandungan hara yang tidak jauh berbeda sehingga dianjurkan tidak menggunakan kombinasi yang sama dari jenis dan fungsi pupuk yang sama.

\section{DAFTAR PUSTAKA}

Bustamam, T., Nalwida, R. dan Wawan, K., 2014. Pengaruh Konsentrasi NAA dan BAP Terhadap Kultur Embrio Pinang Sirih (Areca catechu L.) Secara In Vitro. Stigma [Online], Volume XII, No.2, 209-

213.repository.unand.ac.id/...faperta $=5 \mathrm{~F}$ 01/2010.type.html [08 Januari 2015].
Health Wealth International, 2010. Panduan Penggunaan Top G2 [Online]. http://ti2hwi.files.wordpress.com/2010/04/1 panduan-aplikasi-pupuk-organik-cair-topg2.pdf [11 Desember 2014

Radian, 1996. Kascing dan Peranannya Dalam Meningkatkan Kesuburan Tanah, Fakultas Pertanian Universitas Tanjungpura, Pontianak.

Simamora, S., 2006. Meningkatkan Kualitas Kompos. Agro Media, Jakarta.

Soepardi, G., 1983. Sifat dan Ciri Tanah. Fakultas Pertanian Institut Pertanian Bogor. Bogor.

Sulastri, Junaidi dan Asadi., 2013. Pengaruh Pemberian Pupuk Organik Kascing Terhadap Sifat Fisik, Kandungan NTotal Tanah Aluvial dan Hasil Tanaman Cabai Besar (Capsicum annum L.). Jspp [Online], Vol 2, No 1, 13 Halaman. http://jurnal.untan.ac.id/index.php/jspp/a rticle/view/2443 [11 Desember 2014].

Wahyudi, I. dan Muhammad, H., 2009. Pengaruh Pemberian Pupuk Kompos dan Urea Terhadap Pertumbuhan Bibit Pinang (Areca catechu L.). J. Floratek [Online], Vol 4, No 1, 17 Halaman. http://www.jurnal.unsyiah.ac.id/floratek/arti cle/view/185 [4 Desember 2014].

Gardner, Et All. 1991. Fisiologi Tanaman Budidaya. Jakarta : UI Press. 